Annales Missiologici Posnanienses t. 25 (2020), s. 23-34

doi: $10.14746 / \mathrm{amp} .2020 .25 .2$

ORCID: 0000-0001-9949-9953

JUSTYNA SPRUTTA

Akademia Finansów i Biznesu „Vistula” w Warszawie.

Filia Akademii im. Aleksandra Gieysztora w Pułtusku

\title{
Chrystianizacja Słowian połabskich
}

Na tle całej Słowiańszczyzny Połabianie zasłynęli jako najbardziej oporni wobec chrystianizacji, dlatego też Połabie stanowiło ostatni bastion słowiańskiego pogaństwa. Zanim Słowianie przybyli na Połabie (VI w.), region ten, czyli obecne północno-wschodnie Niemcy, zamieszkiwali Germanie. Połabie, obejmujące obszar między Morzem Bałtyckim, Łabą, Hawelą i Odrą, graniczyło z Lubuszanami, Pomorzanami, Sasami i plemionami czeskimi. Połabianie należeli do grupy Słowian zachodniopomorskich. Andrzej Wędzki podaje też, że w węższym znaczeniu stanowili oni jedno z plemion obodrzyckich (Mały słownik kultury dawnych Słowian 300).

\section{Zarzewie konfliktu}

Należy przyjrzeć się wpierw pokrótce przyczynom konfliktu, jaki zaistniał między światem pogańskim Połabia a światem chrześcijańskim Zachodu. Najogólniej rzecz ujmując, można stwierdzić, że jego powodem był opór Słowian połabskich wobec chrystianizacji. Postrzegali ją jako zagrożenie m.in. dla swej niezależności i narodowej tożsamości. Zdeněk Váňa pisze: „[religia pogańska Połabian jawiła się - J.S.] aż do XII w. jako broń ideologiczna w walce o utrzymanie niepodległości, ponieważ niesione przez zachodnich misjonarzy chrześcijaństwo oznaczało dla nich [Słowian połabskich - J.S.] jedynie zniewolenie i stopniowe wynarodowienie" (Váňa 84).

Za niepowodzenie w zaprowadzaniu chrześcijaństwa winił Słowian Helmold, dwunastowieczny kronikarz z Bozowa nad Jeziorem Płońskim, zresztą niedarzący ich sympatią. Oskarżał też wyprawy normańskie, a także krytykował samych misjonarzy za bezowocność chrystianizacji, mimo iż jednocze- 
śnie uwypuklał ich heroiczną wręcz gorliwość. Pisał o Połabiu, że jedynie ta „kraina Słowian pozostała bardziej oporna od innych i nieskłonna do przyjęcia wiary", dopowiadając, że nie budzi zdumienia fakt, iż

najgodniejsi kapłani i głosiciele ewangelii, Ankar, Rimbert i [...] Unni, wszyscy wyróżniający się niezwykłą gorliwością w nawracaniu pogan, nie troszczyli się o zbawienie Słowian, tak że ani sami, ani przez podwładnych sobie kapłanów nie zebrali żadnego owocu. Taki stan [...] spowodował niedający się przezwyciężyć upór tego ludu a nie niedbalstwo misjonarzy, których serca pałały chęcią nawrócenia pogan, [tak - J.S.] że nie szczędzili ani majątku, ani życia (Helmold 101).

Dziejopis Adam z Bremy, kanonik i mistrz szkoły katedralnej w tym mieście, powodu oporu Połabian wobec chrystianizacji dopatrywał się m.in. w niestosownej postawie samych chrześcijan. Wskazywał chociażby na chciwość saskich książąt jako jedną z przyczyn odradzania się pogaństwa, dominującą nad właściwą powinnością, jaką stanowiło nawracanie pogan na chrześcijaństwo (Głosik 11). Z chciwości słynął np. biskup merseburski Thietmar, pomnażający swój biskupi majątek przez uprzedmiotowienie podlegających mu Słowian, czyli de facto ich wykorzystywanie w celach ekonomicznych. Takie zachowanie Słowianie uważali za odrażające, dlatego nie tylko zwrócili się ku pogaństwu, ale i postanowili pozbyć się chciwych hierarchów kościelnych z Połabia (Barkowski, Połabie 983 138). Wśród tych Słowian znaleźli się sprawujący po podziale rządy nad Wągrami, Połabianami i Obodrytami Przybysław i Niklot, o których Helmold pisał, że „byli strasznymi bestiami, bardzo wrogo usposobionymi względem chrześcijan", twierdząc ponadto, iż pod ich panowaniem odrodziło się na Połabiu pogaństwo (Helmold 173).

Co więcej, uzmysłowiwszy sobie, że konsekwencją przyjęcia chrześcijaństwa będzie płacenie książętom trybutu, Słowianie sięgnęli po oręż, zwracając go również przeciwko misjonarzom, przekonani, iż z jego pomocą ocalą religijną i ekonomiczną wolność. Wierzyli też w skuteczność opieki sprawowanej nad nimi, także w walce, przez ich bogów i boginie, których wizerunki widniały na sztandarach, czyli płachtach umieszczonych między drzewcami ${ }^{1}$. Zanim wyruszyli do walki z chrześcijanami, prosili w swych świątyniach bóstwa

${ }^{1}$ Istotną funkcję przypisywano tym sztandarom. W okresie pokoju przechowywano je w świątyniach, a w czasie wojennych wypraw noszono na czele armii przez broniących ich w razie konieczności pieszych wojowników wyznaczonych specjalnie do tego zadania: noszenia i obrony. Na sztandarach widniały wizerunki pogańskich bogów i bogiń. O obecności takich sztandarów wzmiankuje Thietmar, gdy pisze o gniewie Wieletów (Luciców) za obrazę ich bogini, ponieważ jeden z ludzi Hermana, margrabiego Miśni, przebił kamieniem jej wizerunek widniejący na lutyckim sztandarze, za co wypłacono Słowianom odszkodowanie w wysokości dwunastu talentów. Co więcej, kiedy Wieleci podejmowali trud przeprawy w pobliżu grodu Vurcin przez rzekę Muldę, utracili drugi wizerunek bogini wraz z towarzyszącymi mu pięćdziesięcioma wojownikami (Thietmar VII 64 (47), s. 209: Chronik) (Ławrynowicz 23; por. Barkowski, Połabie 983 130-131). 
o triumf, np. utożsamianego ze Swarożycem Redigasta (vel Radogosta) w Radogoszczy zwanej przez Adama z Bremy Retrą. O owej „siedzibie pogaństwa” i posągu wspomnianego boga kronikarz ten pisał, że wznosi się w Retrze „wielka świątynia dla bożków, których głową jest Redigast. Podobizna jego jest ze złota, łoże jego z purpury sporządzone”, dopowiadając też, iż

drewniany most [w Radogoszczy - J.S.] umożliwia przejście dostępne tylko dla kapłanów albo proszącym o wyrocznię z tej, jak sądzę, przyczyny, żeby zgubione dusze tych, którzy bożkom służą, Styks tym wygodniej ogarnął dziewięciokrotną falą (cyt. za Labuda 206; por. Łowmiański 174).

Niemniej jednak po ciosie zadanym Radogoszczy w 1068 r., przestała ona stanowić centrum tamtejszego pogaństwa: kult Swarożyca przeniósł się z tego miasta do ziemi Obodrytów (Łowmiański 171)2 ${ }^{2}$ Jednym z komponentów kultu u pogańskich Połabian były ofiary składane z chrześcijan, najczęściej przez ich dekapitację. Manifest z 1108 r., autorstwa arcybiskupa magdeburskiego Adalgota, mówi m.in. o wystosowanym przez ,ich [pogańskich Słowian - J.S.] czarowników [kapłanów - J.S.]" żądaniu głów na ofiarę z okazji świąt dla pragnącego takiej ofiary „Pripegala”, czyli „Priapsa i bezwstydnego Belfegora” (Labuda 805). Dalej jeszcze Adalgot informuje, że „ściąwszy chrześcijanom głowy przed ołtarzami swej profanacji, biorą [poganie - J.S.] w ręce puchary pełne krwi ludzkiej i, wyjąc strasznym głosem, wołają: „Święćmy dzień radości! Zwyciężony jest Chrystus! Zwyciężył niezwyciężony Pripegala!” (cyt. za Labuda 805).

Najbardziej znanym połabskim przykładem męczeńskiej śmierci misjonarza przez dekapitację są ostatnie chwile doczesnej egzystencji biskupa meklemburskiego Jana, o czym piszą Helmold i Adam z Bremy. Śmierć tego hierarchy miała miejsce w dniu 11 listopada 1066 r. w Radogoszczy. Zanim przewieziono go do owego miasta, biskup Jan zajmował się misją ewangelizacyjną w Mechlinie (Meklemburg), gdzie ujęto go wraz z innymi chrześcijanami. Zanim zadano mu śmierć, obwożono wiekowego już biskupa-misjonarza po sąsiadujących z Radogoszczą grodach i osadach, wyszydzając i okładając rózgami za wiarę w Jezusa Chrystusa. Nie tylko pozbawiono hierarchę głowy, lecz także odrąbano mu ręce i nogi, porzuciwszy jego okaleczone ciało na uli-

${ }^{2} \mathrm{O}$ czci Radogosta w tym mieście wspomina np. Thietmar, nie omieszkując nawiązać do pogańskiego, przerażającego dziwa Głomacza, czyli jeziora, z którego wyłaniał się odyniec tarzający się w sąsiadującej z jeziorem kałuży, oraz do świętego gaju w diecezji merseburskiej i okręgów ze świątyniami z wizerunkami pogańskich idoli. Zdaniem Gerarda Labudy Thietmar pisze o kulcie Swarożyca w Radogoszczy jako bezpośredni świadek i kościelny dygnitarz obracający się w kręgu stykającym się wprost z Redarami, w przeciwieństwie do Adama z Bremy, który pisząc o lokalizacji Radogoszczy, dodaje: ,jak powiadają”, stąd w tej kwestii zapiski bremeńskiego kronikarza jawią się jako mniej wiarygodne (Labuda 206, 208; Thietmar 130-131 za Labuda 204, 209). 
cy, nabiwszy ogoloną głowę biskupa z wyciętym na niej mieczem, aż do kości, znakiem krzyża na włócznię i ofiarowawszy ową głowę Redigastowi jako dowód triumfu (Helmold 84; Łowmiański 185; Gieysztor 58; Berkowski, Potabie 983 164). Autor scholii do kroniki Adama z Bremy wspomina natomiast dwóch czeskich mnichów, nieznanych z imienia, których również pozbawiono życia, poprzedzając ich śmierć torturami. Krwawe obchodzenie się pogańskich Połabian z chrześcijanami sugeruje też Brunon z Kwerfurtu w liście z 1008 r., adresowanym do Henryka II, w którym oskarża cesarza Niemiec o sprzymierzenie się z pogańskimi Wieletami z Połabia, mającymi wspomóc go w walce z piastowskim księciem Bolesławem Chrobrym, a także o tolerowanie kultu urągającego chrześcijaństwu, domagającego się krwawych ofiar z chrześcijan. Zadaje adresatowi listu następujące pytanie:

W jaki sposób mogą zgodzić się diabeł Swarożyc oraz wódz świętych, wasz i nasz Maurycy? Jakim czołem schodzą się święta włócznia i chorągwie diabelskie tych, którzy poją się krwią ludzką? (Brunon z Kwerfurtu 255-256).

W bezlitosnym postępowaniu pogańskich Połabian z chrześcijanami dostrzega się nie tylko odwet wzięty na chrześcijanach, ale i konsekwencję chęci skutecznego zastraszenia chrześcijan, których krew jako ofiarę preferowały, o czym byli zresztą przekonani połabscy Słowianie, ich bóstwa. Okrucieństwo jawiło się zatem tutaj jako chroniące przed chrześcijaństwem. Męczeństwo wpisywało się w chrystianizacyjny trud spowodowany oporem Połabian, wyrosłym z obaw m.in. przed utratą tożsamości i niezależności oraz z niechęci do niestosownie postępujących chrześcijan i lęku przed zewnętrzną, obcą hegemonią. Opór ten nie przyczynił się do rezygnacji z prób chrystianizacji Połabia, a może nawet wzmocnił chęć obalenia ostatniego bastionu słowiańskiego pogaństwa.

\section{Zaprowadzanie chrześcijaństwa na Połabiu}

Początki chrystianizacji Słowian zamieszkujących obecne północno-wschodnie Niemcy sięgają epoki karolińskiej. W 789 r. Karol Wielki, wyprawiwszy się na Wieletów (vel Luciców), nie narzucił im jednak (i Obodrytom) wiary chrześcijańskiej ${ }^{3}$, lecz frankońskie zwierzchnictwo. Dopiero około 800 r. polecił biskupowi Würzburga Bernwelfowi wznieść czternaście kościołów dla schrystianizowanych Słowian mieszkających nad rzekami Men i Regnitz (Czapliński, Galos i Korta 72). Ludwik Pobożny, syn Karola Wielkie-

\footnotetext{
${ }^{3}$ Należy dopowiedzieć, że Obodryci nie dość, iż w wojnie Franków z Sasami poparli Karola Wielkiego, to wzięli udział w wojnie Pepina z Sasami w 748 r. W przeciwieństwie do nich Wieleci widzieli dla siebie zagrożenie w podbojach tego władcy (Czapliński, Galos i Korta 72).
} 
go, napisał natomiast w latach 826-830 list do biskupa z Würzburga, prosząc w nim o ochrzczenie Wieletów i Obodrytów.

Chrystianizacji Połabian towarzyszyła też chęć ich politycznego uzależnienia, dlatego bronili się, zresztą skutecznie, także w X stuleciu (i później), przed zakusami niemieckich kolonistów. Warto w tym momencie dopowiedzieć, że w 928 r. Henryk I Ptasznik zainicjował podbój ziem Wieletów i Obodrytów, a jego następca Otton I, dążąc do politycznego i religijnego podporządkowania sobie Słowian, wzniósł w 948 r. na ich ziemiach podlegające arcybiskupstwu w Moguncji biskupstwa: dla północnych plemion Wieletów w Hobolinie (Havelberg), dla Wagrów i Obodrytów w Stargardzie Wagryjskim (Oldenburg) i dla pozostałych Słowian (zamieszkujących obszar od Szczecina po rzeki Hobolę i Sprewę) w Brennie (Brandenburg), przekonany, że w przeciwieństwie do wzmożonej chrystianizacji podbitych plemion i poddania ich jednolitej organizacji kościelnej militarny triumf i przemoc nie zagwarantują trwałego, niemieckiego panowania nad Słowianami zamieszkującymi obszar między Łabą i Odrą. Podjęto również decyzję o ustanowieniu biskupstwa na ziemi Obodrytów, ale plan ten załamał się za panowania Ottona II (Łowmiański 170). Co więcej, klęska Ottona II w bitwie z Arabami w Kalabrii i jego śmierć w 983 r. stały się sygnałem do wybuchu powstania, którego inspiratorami byli wieleccy Redarowie, obalenia niemieckiego panowania i w efekcie do zniweczenia powiązanej z celami politycznymi misji chrystianizacyjnej wśród Połabian chcących zachować polityczną niezawisłość, rodzimą kulturę, kult i obyczaje, a zbrojnie występujących przeciwko niemieckiemu uciskowi, samowoli i przemocy. Złą sławą w ich oczach cieszyli się chociażby margrabia Teodoryk, książę saski Bernard i biskup Brenny Dodilon. Buntowi przewodził Mściwój, a po nim Mścisław (por. Ludat 158-163). Pod wodzą Mściwoja występujący przeciwko Niemcom w ślad za Wieletami Obodryci zniszczyli biskupstwo w Stargardzie Wagryjskim, rozbili niemieckie wojska nad rzeką Muldą i zdewastowali Hamburg. Zniszczono podczas owego powstania także biskupstwa misyjne w Brennie i Hobolinie. W Brennie, gdzie przebywali wtedy margrabia Teodoryk i biskup Folkmar, po zburzeniu, tak jak i w Hobolinie, kościołów Wieleci m.in. wyrzucili z grobu szczątki znienawidzonego biskupa Dodilona. Następnie, połączywszy siły, Wieleci i Obodryci ruszyli na Magdeburg, jednakże niemiecka obrona, o jaką zabiegał zwłaszcza tutejszy arcybiskup Gizyler, pokonała powstańców w bitwie nad rzeką Tongerą: Słowianie musieli opuścić Saksonię i wycofać się na prawy brzeg Łaby. Organizacja kościelna przetrwała wówczas jedynie na terenie Miśni i Łużyc (Czapliński, Galos i Korta 107-108).

\footnotetext{
${ }^{4} \mathrm{~W} 985$ r. książę polski Mieszko I udzielił niemieckiemu cesarstwu wojskowej pomocy w walce ze Słowianami połabskimi (Czapliński, Galos i Korta 109).
} 
Mówi się wręcz o fali słowiańskich powstań na Połabiu, będących konsekwencją sprzeciwu Połabian wobec niemieckiego panowania oraz stawiania oporu de facto wzmożonej chrystianizacji i powiązanej z nią feudalizacji. Owe zbrojne wystąpienia Słowian połabskich sprowokował w 954 r. napad margrabiego Gerona na wieleckich Wkrzan, spowodowany obawami przed ich rychłym wyłamaniem się, z racji peryferyjnego usytuowania, spod cesarskiego zwierzchnictwa i anulowaniem sięgających epoki Henryka I powinności trybutarnych. Sygnał do powszechnego, antyniemieckiego powstania dał w 955 r. najazd węgierski. Jednakże w starciu z powstańcami zatriumfował, dzięki przewadze militarnej, Otton I. Po tym zwycięstwie niemieckie duchowieństwo ponownie podjęło się chrystianizacji Słowian. Ponadto, dzięki poparciu udzielonemu przez Ottona I i przychylności papieża Jana XIII, utworzono w 968 r. nowe arcybiskupstwo: w Magdeburgu, obejmujące administracyjnym zasięgiem nowe biskupstwa w Merseburgu, Żytycach i Miśni, mające rozwinąć chrześcijaństwo wśród Serbów łużyckich i umacniać na ich przygranicznych ziemiach niemieckie panowanie, tudzież od 1030 r. biskupstwo w Naumburgu, a także dawne biskupstwa: w Brennie i Hobolinie (por. Czapliński, Galos i Korta 101-102). Magdeburskiego metropolitę wspomniany papież ustanowił prymasem Kościoła w Niemczech: od Renu po Odrę. Biskupstwo w Stargardzie Wagryjskim (Oldenburg) podporządkowano natomiast metropolii hambursko-bremeńskiej (Banaszak 51).

W X stuleciu ziemie Słowian przekształciły się we wschodnie marchie Cesarstwa Niemieckiego z utworzonymi w nich biskupstwami jako zalążkiem chrystianizacyjnej misji czyniącej swoim adresatem tutejszych Słowian. W X i XI w. nawracaniem Połabian przemocą zajmowało się duchowieństwo archidiecezji magdeburskiej. Ponadto na jedenaste stulecie przypadło panowanie połabskiego księcia Gotszalka, którego dziadkiem był wspomniany powyżej Mściwój (por. Ludat 164-174). Gotszalk zasłynął w historii jako założyciel państwa Obodrytów, odegrawszy niebagatelną rolę w ich powiązanej z politycznym podbojem chrystianizacji. Następująco o Gotszalku pisze w Kronice Stowian Helmold:

Niech więc sławiony będzie i wszelką chwałą okryty najgodniejszy Gotszalk, który mimo swego barbarzyńskiego pochodzenia na nowo z pełnym poświęceniem przywrócił swemu ludowi dar wiary świętej i łaskę chrześcijaństwa (Helmold 80).

Sprzyjający chrystianizacji Obodrytów i zajmujący się nią Gotszalk zjednoczył obodrzyckie plemiona. Znalazłszy poparcie u arcybiskupa Adalberta z Bremy, zabiegał o pokojową chrystianizację swego kraju, wzorując ją na podjętej pod koniec X w., za radą biskupa Pragi Wojciecha, działalności przez Ottona III. Jednakże, jako że Gotszalk zamierzał utworzyć nad Bałtykiem niezależne, lecz pozostające w feudalnym związku z Cesarstwem Niemieckim 
państwo chrześcijańskie, został ścięty pod koniec 1066 r., a wraz z nim zginął też mnich Eppon. Był to jeden ze skutków zainicjowanego przez Wieletów nawrotu do pogaństwa. Ponadto Obodryci, na czele z Błusem, zniszczyli w 1066 r. m.in. Hamburg, zmuszeni znacznie wcześniej, po najeździe na nich Niemców w 931 r., do przyjęcia chrześcijaństwa. Kilkadziesiąt lat po śmierci Gotszalka, jego syn Henryk obalił około 1093 r. odrodzone pogaństwo i stał się władcą Obodrytów (Váňa 211). Po zgonie Henryka i krótkotrwałym panowaniu Duńczyków nad jego księstwem podzielili je między sobą Przybysław i Niklot. Rezydujący w Lubece Przybysław zasłynął z korsarskich wypraw do Danii, a Niklot założył meklemburski ród książęcy, z czasem zgermanizowany, który utrzymał swoją władzę aż do 1918 r. (por. Barkowski, Połabie 983 72).

Rządzone przez Przybysława i Niklota terytorium stało się w 1147 r. priorytetowym celem krucjaty przeciwko pogańskim Obodrytom i Wieletom. W tym samym stuleciu, kiedy to w latach 1102-1128 Polacy podbijali Pomorze a biskup Otton z Bambergu prowadził (1124 i 1128 r.) pod auspicjami Bolesława III Krzywoustego kampanię chrystianizacyjną, biskupi misyjni coraz częściej postrzegali pogańskich Połabian jako docelową grupę konwersji na chrześcijaństwo. Jednakże, kiedy np. Otton z Bambergu zamierzał wyprawić się po walkach Szczecinian z Rugianami z misją ewangelizacyjną na Rugię, jej pogańscy mieszkańcy poprzez poselstwo zagrozili mu, jeśli to uczyni, dekapitacją i rzuceniem biskupiego ciała na pożarcie dzikim zwierzętom, podobnie grożąc też jego emisariuszom (Wejman 251).

Do krucjaty przeciwko pogańskim Połabianom wzywał św. Bernard z Clairvaux na sejmie niemieckim we Frankfurcie, za pontyfikatu papieża Eugeniusza III. Apel tego cystersa wystosowany został w formie listu 457, zatytułowanego Do wszystkich wierzacych. Owo wezwanie interpretowano jako wezwanie wyznawców Jezusa Chrystusa do zbrojnego zmagania się z nieprzyjaciółmi wiary chrześcijańskiej. Wymagało ono podjęcia przez każdą prowincję Kościoła walki z poganami zamieszkującymi najbliżej położone ziemie. Co więcej, w dniu 12 marca 1147 r. Henryk Lew i Albrecht Niedźwiedź zwrócili się we Frankfurcie do św. Bernarda z Clairvaux z prośbą o udzielenie im poparcia $\mathrm{w}$ staraniach o papieskie pozwolenie na uczestniczenie w krucjacie przeciw pogańskim Połabianom zamiast w krucjacie do Ziemi Świętej, motywując swoją niechęć do udziału w drugiej z wymienionych wypraw krzyżowych daleką drogą i gnieżdżącym się w ich pobliżu pogańskim zagrożeniem dla chrześcijańskiego świata. Znaleźli poparcie u św. Bernarda z Clairvaux. Ponadto papież Eugeniusz III poświęcił połabskiej krucjacie bullę Divini dispensatione („,O Bożych dyspensach”) z dnia 11 kwietnia $1147 \mathrm{r}$. Rozszerzała ona przyznane krzyżowcom przywileje na podejmujących walkę z Połabianami. Poza tym wspomniany francuski cysters, oprócz obwieszczenia papieskiej aprobaty dla połabskiej krucjaty, zapowiedział, że jej uczestnicy 
nie mogą zawierać z poganami jakiegokolwiek rozejmu do momentu, w którym poganie ci ,z Bożą pomocą albo zostaną nawróceni, albo zmieceni z powierzchni ziemi"”5 (cyt. za von Güttner-Sporzyński 209).

W połabskiej krucjacie wzięli udział m.in.: dowodzący książę saski Henryk Lew (opanował ziemie Obodrytów) i margrabia Albrecht Niedźwiedź z Marchii Północnej (zdobył w 1157 r. Brennę i nadał jej nazwę: Brandenburg), a także margrabia Konrad Wettin z Miśni, biskupi z Magdeburga i Bremy, papieski legat Anzelm - biskup z Havelbergu, Sasi, Duńczycy (wraz z flotą), Czesi (rycerstwo morawskie) i Polacy. Na początku lipca 1147 r. krzyżowcy, na czele z Henrykiem Lwem, wsparci przez duńską flotę oblegli Dobin. Po pierwszych stratach zawarto rozejm. Zgodnie z jego warunkami uwolniono duńskich jeńców, połabski władca nominalnie nawrócił się i ponownie Połabianie zaczęli płacić daninę. Na czele drugiej armii krzyżowców, którą współtworzył polski kontyngent, stali Albrecht Niedźwiedź i biskup Anzelm z Havelbergu. Krzyżowcy ci nie zdołali zdobyć grodu Dymina (ani Szczecina). Dopiero w związku z oblężeniem Malachowa Niklot uznał zwierzchnictwo Saksonii. Krucjata rozproszyła się przed końcem września. Mimo iż nie odniosła wielkiego, militarnego sukcesu, spustoszyła kraj i zdziesiątkowała ludność, doprowadziwszy do zniewolenia tamtejszych plemion. Zamiast dla chrystianizacji połabską krucjatę wykorzystano dla celów politycznych, a Przybysław i Niklot postanowili pod wpływem zadanego im przez krzyżowców ciosu przyjąć chrzest i uznać zwierzchnictwo Henryka Lwa. Po mającej miejsce w 1150 r. śmierci Przybysława ziemią Wieletów przejściowo władał Albrecht Niedźwiedź (por. von Güttner-Sporzyński 208-210; Barkowski, Krucjata połabska 1147 12; por. Manteuffel 300-301). Następująco o odejściu dawnego świata pisze Z. Váňa: „Ich [Przybysława i Niklota - J.S.] pogański świat wierzeń w swej schyłkowej $i$ atawistycznej postaci nie miał żadnych szans przetrwania wobec wyżej stojącej cywilizacji chrześcijańskiej" (Váňa 100).

Co więcej, o zaplanowaniu wcześniejszej krucjaty przeciwko pogańskim Połabianom można mówić już w 1108 r. W powstałym wtedy w Magdeburgu dokumencie nawoływano do wojny w obronie chrześcijańskich wspólnot i do nawracania żyjących w pobliżu pogan. Dokument ten, autorstwa nieznanego imiennie mnicha $\mathrm{z}$ otoczenia Adalgoda, biskupa Magdeburga, zaadresowany został do Adagolda, pięciu podlegających mu biskupów sufraganów, w tym do dwóch przebywających na wygnaniu - Ezelina z Hobolina i Hartberta z Brenny, i do możnych Saksończyków, zatem do duchowieństwa i laikatu z Saksonii, Frankonii, Flandrii i Lotaryngii. W Petitio, czyli najważniejszej jego części, wezwano adresatów do uczestniczenia w skutecznej chrystianizacji

\footnotetext{
${ }^{5}$ Nie wiadomo, czy aby na pewno św. Bernard z Clairvaux miał na uwadze fizyczne unicestwienie pogan, jednakże uczestnicy krucjaty potraktowali jego wypowiedź literalnie.
} 
Połabia i do restytucji zniszczonych instytucji Kościoła, natomiast w Narratio wyjaśniono i uzasadniono wezwanie do krucjaty, opisując wpierw brutalność i okrucieństwo pogańskich Połabian względem chrześcijan. Nadto opisano w nim skrupulatnie pogańskie miejsca kultu i idole. Dokument ten nęcił potencjalnych krzyżowców ocaleniem duszy i ziemią jako zdobyczą, nakłaniając ich do wyruszenia tropem Franków i wyzwolenia pobliskiego Jeruzalem z rąk Połabian, najokrutniejszych z pogan, atakujących chrześcijan i profanujących kościoły. Owo wezwanie do krucjaty przeciwko Połabianom nie pociągnęło za sobą oczekiwanego skutku. Nie zrealizowano tego planu, ponieważ prawdopodobnie ważniejsze dla Henryka V okazały się od połabskiej krucjaty: interwencja na Węgrzech i przygotowania do wojny z Polską (von Güttner-Sporzyński 205-206; por. Barkowski, Krucjata połabska 1147 58-59).

Dopiero w drugiej połowie XII stulecia zadano ostateczny cios połabskiemu pogaństwu. Wcześniej, po zniszczeniu w 1068 r. Radogoszczy, jej rolę centrum pogaństwa - przejęła około 1100 r. Arkona, gród na Rugii, w którym szczególną czcią darzono w XI i XII w. Świętowita. To właśnie w Arkonie znajdował się wyobrażający go posąg o czterech obliczach i z metalowym rogiem do picia w prawej dłoni, strzeżony w świątyni przez trzystu wojów (por. Maly słownik kultury dawnych Słowian, 19). Corocznie ofiarowywano arkońskiemu Świętowitowi wziętych do niewoli chrześcijan (por. Váňa 91-92), a Słowianie z Rugii „cieszyli się opinią zatwardziałych pogan i ze wszystkich Słowian najdłużej opierali się chrystianizacji” (Váňa 92; por. Büttner). Co więcej, w Radogoszczy poświęcono Swarożycowi siwego, wieszczącego konia dosiadanego jedynie przez pogańskiego kapłana (taki koń znajdował się również w Arkonie). Kiedy w 1068 r. zniszczono świątynię w Radogoszczy, na grzbiecie „należącego” do Swarożyca konia, na oczach pogan i „poganom ku hańbie”, biskup Burchard udał się do swej siedziby w Halberstadt (Váňa 9).

Kiedy w 1168 r. na Rugię wtargnęli Duńczycy, zniszczyli ją wraz z Arkoną - ostatni bastion słowiańskiego pogaństwa i niezawisłości pogańskich Połabian. Rugia stała się pierwszym celem Duńczyków toczących na Bałtyku walkę z pogańskimi piratami wendyjskimi i estońskimi. Zresztą jest to zrozumiałe, jeśli uwzględni się fakt, że mieszkańcy Rugii stale atakowali wybrzeże Danii. Wtedy to duński król Waldemar I, wsparty przez książęta Pomorza, podbił Rugię i podporządkował arcybiskupstwu w Lund (Wejman 252). Podbiwszy ją, nakazał obalić arkoński posąg Świętowita, przywiązać do jego szyi sznur i zawlec rzeźbę w ogień (Gieysztor 91). Zniszczył też pogańską świątynię w Arkonie, zmusił mieszkańców Rugii do przyjęcia chrztu oraz założywszy sieć cysterskich klasztorów, zainicjował chrystianizację tutejszych Słowian'.

\footnotetext{
${ }^{6}$ Ostatnią, obszerną relację o pogańskiej religii Połabian z Rugii przekazał Saxo Gramatyk, duński kronikarz żyjący w XII-XIII w. Należy też wspomnieć o uzupełniającej tę relację w pewnym
} 
Warto też podkreślić, że przypuszczalnie na Rugię mogła dotrzeć, być może przez Czechy, nieznana bliżej misja z kręgu cyrylo-metodejskiego (von Güttner-Sporzyński 213; Bednarczuk 15; Łowmiański 196-198), a jej obecności dowodziłyby występujące na miejscu cerkiewizmy, takie jak chociażby: püp (,ksiądz, pastor”) i pąt'üste („Zielone Świątki”), czy toponimy, np. Crisov (Bednarczuk 15). Ponadto chrześcijaństwo przenikało na Połabie również drogą religijnego synkretyzmu: przez kojarzenie i adaptowanie imion świętych z pogańskimi bogami, o czym świadczą takie określenia jak np.: Święty Wit - Suentewith, Trójca Święta - Triglav czy Diabeł - Zernebog (Czarny Bóg) (Bednarczuk 15).

Po upadku Rugii Słowianie połabscy zaczęli tracić własną, narodową tożsamość, ponieważ zamieszkiwany przez nich region otwarto na zakrojoną szeroko kolonizację z Zachodu i wiążącą się z nią germanizację. Po upływie dwóch, trzech stuleci od tego momentu utracili oni swą narodowość, stając się w konsekwencji tego kroku już na zawsze częścią Niemiec (por. Váňa 213).

Los pogańskich Połabian przypieczętowali Duńczycy w drugiej połowie XII stulecia. Wbrew wielu próbom Słowianie połabscy nie zdołali obronić swej tożsamości, dla której nie bez znaczenia była także pogańska religia. Dostrzegali w niemieckiej chrystianizacji realne zagrożenie dla owej tożsamości, a antyświadectwo możnych chrześcijan, duchownych i świeckich nie zachęcało ich do przyjęcia chrztu, natomiast neofitów skłaniało do powrotu do dawnych wierzeń. W tym kontekście Arkona jako ostatni bastion słowiańskiego pogaństwa w północno-wschodnich, dzisiejszych Niemczech jawi się i dzisiaj jako wymowny symbol upadku dawnego świata na rzecz nowego, który pozbawił Połabian słowiańskiej tożsamości, czyniąc ich „Niemcami”.

\section{Zakończenie}

Spośród plemion słowiańskich to właśnie Połabianie zasłynęli jako stawiający przez wieki najbardziej zacięty opór chrystianizacji, dlatego Połabie jawiło się i jawi jako ostatni bastion pogaństwa Słowian. Występując przeciwko wprowadzaniu chrześcijaństwa na Połabiu, pogańscy Słowianie łączyli chrystianizację z możliwością utraty swej autonomii. Definitywnie utracili ją poniekąd wraz z upadkiem Arkony, z czasem stając się częścią Niemiec i zatracając swoją słowiańską tożsamość. Z epoki pogańskiej przeszli do epoki chrześcijańskiej de facto dopiero w drugiej połowie XII stulecia, mimo iż już

zakresie Knytlingasadze z drugiej połowy XIII w. Oba utwory czerpały z pochodzącego z końca XII stulecia wspólnego źródła: powstałego po podboju Rugii i ukazującego chrześcijańską misję na jej obszarze (por. Głosik 12). 
wcześniej chrześcijaństwo było na Połabiu obecne, o czym świadczyły np. biskupstwa. Słowiańskie Połabie jako ostatnie przyjęło chrzest.

\section{THE CHRISTIANISATION OF POLABIAN SLAVS}

\section{Summary}

The Polabian Slavs were the last refuge of paganism in the Slavic region. They survived until 1168, because then Rugen, the last pagan bastion of the Slavs after the destruction of Radgosc, was conquered by Waldemar I, king of Denmark. The Polabian Slavs put up the longest resistance to Christianization, seeing it as a threat to their identity, nationality and tradition, of which the pagan cult was an important part. Even in 1147 a crusade was organized against the pagan Polabians, for which St. Bernard of Clairvaux called. The world of pagan Slavs ended with the moment of fall of Rügen and its Arkona, which became the centre of Slavic pagan cult after Radogosc. Two or three centuries later, Polabian Slavs were germanized, losing their nationality and thus becoming the part of Germany.

Keywords: The Polabian Slavs; paganism; the pagan cult; Christianization; Radogosc; Rugen

Słowa kluczowe: Słowianie połabscy; pogaństwo; kult pogański; chrystianizacja; Radogoszcz; Rugia

\section{BIBLIOGRAFIA}

Banaszak, Marian. Historia Kościoła katolickiego. Średniowiecze. T. 2. Warszawa: Wydawnictwo ATK, 1987.

Barkowski, F. Robert. Krucjata połabska 1147. Warszawa: Bellona, 2017.

Barkowski, F. Robert. Połabie 983. Warszawa: Bellona, 2015.

Bednarczuk, Leszek. Językowe drogi chrystianizacji Polski, Poznańskie Spotkania Językoznawcze (2017) 34: 7-34.

Brunon z Kwerfurtu. „List do króla Henryka II.” Piśmiennictwo czasów Bolesława Chrobrego. Tłum. Kazimierz Abgarowicz. Warszawa: PWN, 1966. 247-256.

Büttner, Bengt. Die pfarreien. Der insel Rügen. Köln: Böhlau, 2007.

Czapliński, Władysław. Galos, Adam. Korta, Wacław. Historia Niemiec. Wrocław: Zakład Narodowy im. Ossolińskich, 1981.

Gieysztor, Aleksander. Mitologia Stowian. Warszawa: Wydawnictwa Artystyczne i Filmowe, 1982. Głosik, Jerzy. W kręgu Światowita. Warszawa: Krajowa Agencja Wydawnicza, 1979.

Güttner-Sporzyński von, Darius. „Od misji do wojny świętej i krucjaty. Chrzest pogan w kręgu środkowoeuropejskim a ideologia krucjatowa.” Chrystianizacja „,Młodszej Europy”. Red. Józef Dobosz, Jerzy Strzelczyk i Marzena Matla. Poznań: Wydawnictwo Naukowe UAM, 2017. 201-220. 
Helmolda Kronika Słowian. Tłum. Józef Matuszewski. Oprac. Jerzy Strzelczyk. Warszawa: PWN, 1974.

Helmolda Kronika Stowian. Dostęp 2 czerwca 2020. <www.zrodla.historyczne.prv.pl>

Labuda, Gerard. Studia nad początkami państwa polskiego. T. 3. Wodzisław Śląski: Wydawnictwo Templum, 2012.

Ludat, Herbert. Siedlung und Verfassung der Slawen: zwischen Elbe, Saale und Oder. Giessen: Wilhelm Schmitz Verlag, 1960.

Ławrynowicz, Olgierd. „Uzbrojenie indywidualne w Kronice Thietmara z Merseburga.” Cum arma per aeva. Uzbrojenie indywidualne na przestrzeni dziejów. Red. Paweł Kucypera i Piotr Pudło. Toruń: Wydawnictwo Adam Marszałek, 2011: 9-32.

Maty stownik kultury dawnych Stowian. Red. Lech Leciejewicz. Warszawa: Wiedza Powszechna, 1988.

Łowmiański, Henryk. Religia Stowian i jej upadek. W. VI-XII. Warszawa: PWN, 1979.

Manteuffel, Tadeusz. Historia powszechna. Średniowiecze. Warszawa: PWN, 1978.

Kronika Thietmara. Tłum. Marian Zygmunt Jedlicki. Kraków: Universitas, 2005.

Thietmar von Merseburg. Chronik. Darmstadt: WBG Academic, 2017.

Váňa, Zdeněk. Świat dawnych Słowian. Tłum. Elżbieta i Józef Kaźmierczakowie. Warszawa: Artia Interpress, 1985.

Wejman, Grzegorz. „Modele chrystianizacji ludów basenu Morza Bałtyckiego - podobieństwa i różnice." Studia Paradyskie (2014) 24: 247-261.

JUSTYNA SPRUTTA, dr nauk teologicznych w zakresie teologii dogmatycznej o specjalizacji teologia ikony (KUL) i dr nauk humanistycznych w zakresie historii o specjalizacji historia sztuki (UKSW), magister filologii polskiej o specjalizacji dziennikarstwo i kreowanie wizerunku (UAM). Wykładowca na Wydziale Teologicznym Uniwersytetu im. Adama Mickiewicza w Poznaniu, w Akademii Humanistycznej im. Aleksandra Gieysztora w Pułtusku (filia warszawskiej Akademii Vistula) i w Prymasowskim Instytucie Kultury Chrześcijańskiej w Bydgoszczy, a także bibliotekarz w strzyżewskiej filii Gminnej Biblioteki Publicznej w Sieroszewicach. Członkini Polskiego Instytutu Studiów nad Sztuką Świata i Poznańskiego Towarzystwa Przyjaciół Nauk. 